\title{
The Insect Family Japygidae (Order Thysanura) in Puerto Rico
}

\author{
Irving Fox ${ }^{1}$

\section{INTRODUCTION}

Members of the family Japygidae lead so obscure a life in the soil that their occurrence in a locality is often not generally known, and this is true as regards Puerto Rico. Since they are pests of sugarcane it seems worthwhile to report a recent finding of the family here.

\section{COLLECTION AND IDENTIFICATION}

On May 15, 1956, at about 11:00 a.m., a collecting party consisting of Víctor Medina (School of Medicine), Alfredo Casta Vélez (Commonwealth Department of Health), Edward R. Williams (U. S. Public Health Service), and the writer, in search of breeding places of Culicoides, took soil samples from the west shore of the Laguna La Torrecilla at the International Airport, Islà Verde, P. R., close to the Air National Guard Installation. From 24 samples of about $350 \mathrm{gm}$. of soil each, taken at a depth of about 1 inch, three specimens of a species of Japygidae were recovered after the soil had been passed through No. 20 and No. 80 sieves under water pressure, and treated by the magnesium sulfate technique, which involves the mixing of small portions of the soil in a saturated solution of magnesium sulfate so that organic matter floats to the surface.

To obtain identification of the species, one of the three specimens was sent to Prof. Jean Pagés of the University of Nancy, France, at the suggestion of Miss Grace Glance, of the U. S. National Museum. Prof. Pagés' determination and comments were as follows:

Paraiapyx (Grassjapyx) species, bahianus-brasilianus group, adult female. The exact specific determination is impossible owing to the lack of correct descriptions; furthermore Silvestri has described as new species or subspecies first or second instar larvae. A revision of the American species of Grassjapyx is necessary before we can determine correctly specimens belonging to this subgenus $(1) .^{2}$

\section{DISCUSSION}

In view of Prof. Pagés' comments concerning the uncertain taxonomy in the subgenus Grassjapy.x Pagés (2), it would not be wise at this time to provide this species with a new name. In his catalogue of the Japygidae

1 Assistant Professor of Medical Entomology, School of Medicine, School of Tropical Medicine, University of Puerto Rico, San Juan 22, P. R.

2 Italic numbers in parentheses refer to Literature Cited, p. 37. 
of the world Silvestri (3) listed Neojapy.x insulanus Silvestri (4) from Puerto Rico, but his species came from Culebra Island. So the present finding represents the first record of the family Japygidae from the mainland of Puerto Rico. Very likely there are more species here, as the genera Parajapy $x$ and Neojapyx include a number of species distributed throughout the Americas $(5,6)$.

Ingram, et al., (7) placed the soil forms which damage sugarcane in two classes: Those of the first class, among which are included the Japygidae,

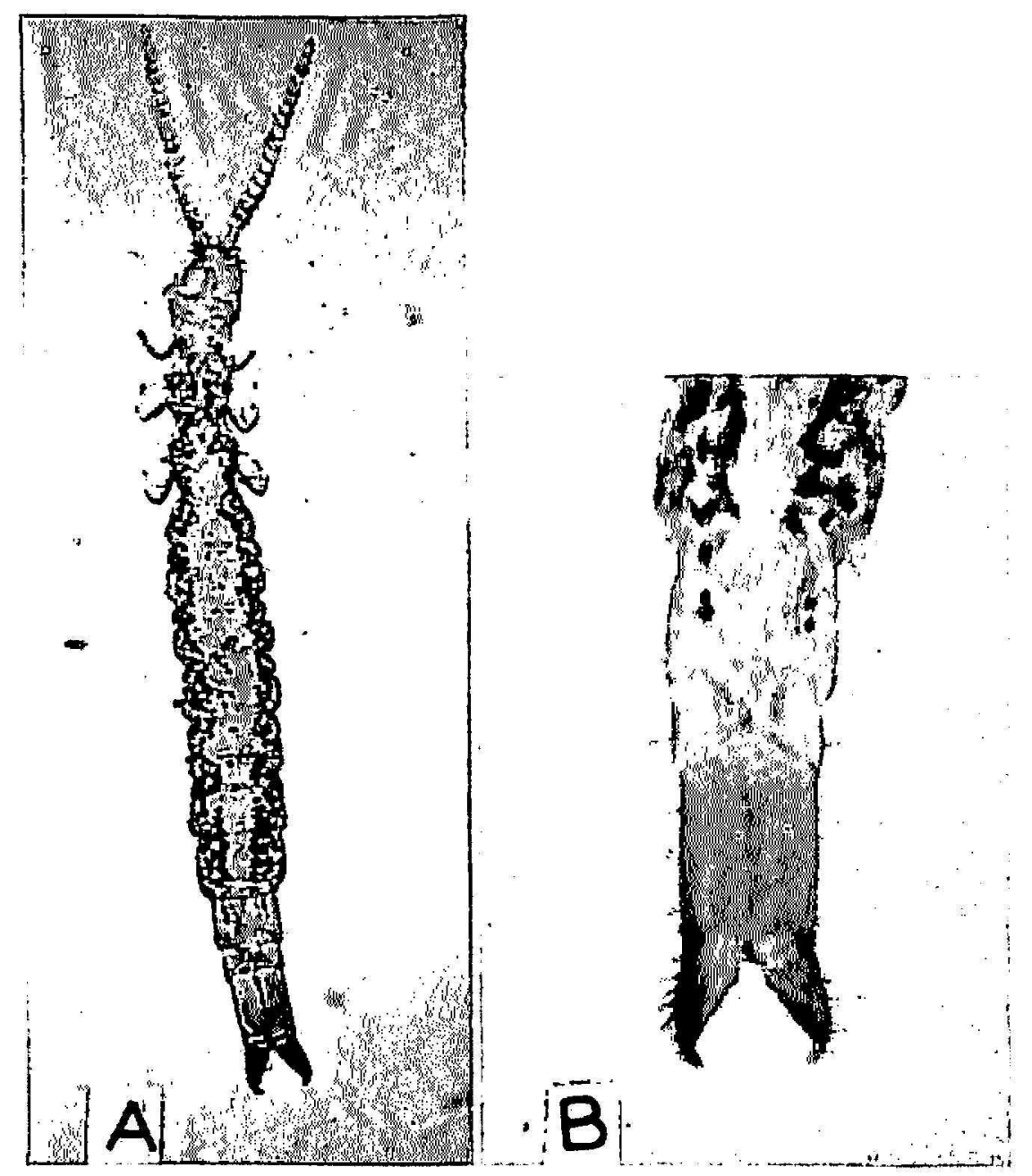

FIG. 1.-A, Parajapyx (Grassjapyx) species, bahianus-brasilianus group; 13, the same, posterior portion of the abdomen.

cut off or gnaw small holes in the roots and prune off root hairs, damaging the root system and checking plant growth, and their gnawing also causes wounds that may provide entry for the causal agents of root rot. Those of the second class include the forms which cause heary injury to the roots, such as weevils and wireworms. In a survey they made in Louisiana 1 square foot of soil at a depth of 8 inches of a sugarcane field yielded 202 specimens of insects of which 30 , or approximately 15 percent, were Jap!s speries. 
Superficially, japygids resemble earwigs in that the cerci are in the form of forceps; however, they differ obviously in details of the thorax and abdomen and in always lacking wings, as shown in figure 1, A. Particularly characteristic is the rectangular tenth abdominal segment to which the forceps are articulated, as shown in figure 1, B. Parajapyx (Grassjapyx) species is exceedingly small, measuring only about $3 \mathrm{~mm}$. in length, including the forceps but excluding the antennae. Other species of Japygidae, such as in the genus Dinjapyx, may be more than $30 \mathrm{~mm}$. long. The three specimens of Parajapyx (Grassjapyx) species collected were disposed of as follows: One specimen in the collection of Prof. Jean Pagés; one in the collection of the U. S. National Museum; and one specimen, the photographs of which are shown in figure 1, in the collection of the School of Medicine, School of Tropical Medicine, University of Puerto Rico, San Juan, P.R.

\section{SUMMARY}

The insect family Japygidae is reported from the mainland of Puerto Rico and its significance as a sugarcane pest is discussed. The family is represented in Puerto Rico by Parajapyx (Grassjapyx) species, taken at the Laguna La Torrecilla, Isla Verde, P. R. and Neojapyx insulanus Silvestri, known from Culebra Island, P. R.

\section{RESUMEN}

El artículo informa la presencia en la isla propia de Puerto Rico de la familia Japygidae de los insectos y discute su importancia como una plaga de las plantaciones de caña de azúcar. Esta familia está representada en Puerto Rico por Parajapyx (Grassjapyx) especie capturado en las playas de la Laguna La Torrecilla, Isla Verde, P. R. y por Neojapyx insulanus Silvestri, ya informado, de la Isla de Culebra, P. R.

\section{LITERATURE CITED}

1. Pagés, J., Personal communication, 1956.

2. turais Companhia Diamentes Angola 13 53-96, 1952.

3. Silvestri, F., Japygidarum et Projapygidarum Catalogus, Bol. Lab. Ent. Agrar. Portici 9 40-75, 1949.

4. - Contributo alla conoscenza degli Japygidae (Insecta Diplura), R. $C$. Soc. Ital. Sci. Accad. XL, Rome 27 3-115, 1948.

5. Fox, Irving, New or little known North American Japygidae (Thysanura), Canad. Ent. 73 28-31, 1941.

6. Ewing, H. E. and Fox, Irving, New Neotropical insects of the Apterygotan family Japygidae, Proc. U. S. Nat. Mus. 92 291-9, 1942.

7. Ingram, J. W. Bynum, E. K., Charpentier, L. J., and Haley, W. E., Chemical control of soil insects and organisms attacking sugarcane, Sugar J.12 13-4, 1950. 